\title{
THE IMPACT OF SOCIAL CAPITAL AND ENTREPRENEURSHIP TO THE PERFORMANCE OF THE STATE-CAPITAL ENTERPRISES (SCE) IN VIETNAM
}

\author{
NGÔ CHÍN, NGUYỄN THUÂN \\ ngochin2023@gmail.com
}

\begin{abstract}
With the continuous effort of the Vietnamese Goverment, there is much research on restructuring State-owned Enterprises (SOE) to establish the State-capital Enterprises (SCE). However, there are few studies on combining intangible resources such as social capital, entrepreneurship despite these resources increase indirectly tangible resources. This study, therefore, tries to build a research model describing (i) the impact of the above resources on SCE performance (ii) the relationship among social capital and performance via entrepreneurship. After adjusting the measurement scales by interviewing specialist in-depth, a quantitative survey was executed using the data collected from 568 SCE and by testing Cronbach's Alpha reliability, EFA, CFA and SEM to comment three proposed hypotheses. The results showed that (i) both social capital and entrepreneurship had positive impacts on performance (ii) social capital had positive impact indirectly on performance through entrepreneurship. Accordingly, the study suggested some practical implications for managers to use properly resources.
\end{abstract}

Keywords: Social capital, Entrepreneurship, performance, State-owned Enterprise (SOE), State-capital Enterprise (SCE).

\section{INTRODUCTION}

In Vietnam, SOE was formed very early (1954 in the North, 1975 in the south) from various sources. $\mathrm{SOE}$ is the backbone of the economy but yielded low operational efficiency. State-capital Enterprises (SCE) are enterprises where the government holds less than 100\% charter capital or equity; capital contribution may not govern; Organized and operated in the form of a joint stock company or twomember limited liability company. The application of adopting social capital solutions to indirectly create tangible resources; to support, coordinate and share; as well as applying the "entrepreneurship" solution to be proactive, innovative, creative and willing to take risks in order to maintain and promote sustainable operation, achieve high efficiency of SCE, is still limited and inefficient, yet there is a lacking of in-depth study on this subject in Vietnam. the previous researchs show that Social capital affects innovation in enterprises (Landry et al., 2000) and social capital also affects entrepreneurship (Cheng-Nan et al., 2007) but has not been tested in Vietnamese SCEs; social capital is effective in reducing risks, contributing to improve performance (Casey, 2002; Woolcock, 2001; Narayan \& Pritchett, 1999; Dasgupta, 2000); entrepreneurship also has a direct positive relationship with organizational performance (Sambrook \& Roberts, 2005); entrepreneurship contributes to creating operational results and is a resource that can create advantages for businesses (Nguyen Thanh Long \& Le Nguyen Hau, 2013); There have been no studies on subject of the combined resources (social capital combining entrepreneurship) which influence and impact on the operational efficiency of SCE in the context of Vietnam, an economy in transformation.

The objective of the study is finding out the correlation relationship between social capital and entrepreneurship; Their impacts on the performance of SCE. Propose solutions to use social capital, entrepreneurship to promote and improve the performance of SCE in the coming time. The research results may have a theoretical contribution about a structural model including second- order factors in which presenting the social capital had positive impact indirectly on performance through entrepreneurship and both social capital and entrepreneurship had positive impacts on performance. 


\section{LITERATURE REVIEW}

\subsection{Main concepts}

Social capital: social capital is a concept that has been concerned, researched, developed and applied systematically and broadly in the fields of economic, educational, social, psychological,... all over the world. Social capital in the most fundamental way of understanding comprises the following the elements: (1) social networks, (2) human beliefs in society, and (3) the possibility of a connection to the implementation of society.

In this study, social capital of enterprise is defined as the synthesis of resources of enterprises (Bourdieu \& Wacquant, 1992) that exist in the network of quality relations with the structure of the network of leaders (Tushman,1997), the external network between enterprises with others (Yang \& et al, 2011), the internal network of enterprises (Brookes \& et al, 2006).

Entrepreneurship: entrepreneurship is a form of strategic demeanor, expressed in the initiative to seek opportunities and fierce competition based on product innovation while willing to accept risks (Covin \& Slevin, 1991). The structure of entrepreneursip consists of 3 components: (1) Proactive (CD), (2) Innovation (DM), (3) Risk taking (RR).

Covin \& Miles (1999) propose four forms of entrepreneurship including [sustained regeneration], [organizational rejuvenation], [strategic renewal], and [do- main redefinition]. The core elements of entrepreneurship are: The ability to seize business opportunities, new venture startups; taking risk; attitude creativity - innovation (creative - innovation); achieve (or reward) sustainable results (reward).

Performance: performance is measured in a variety of ways including assessing business success (Kennerley \& Neely, 2003) and quantifying the results and effectiveness of managing an organization's operations (Neely. et al., 1995). Business performance can also be measured through the application of objective and subjective indicators. Chu (2015) is a typical use of a scale to measure the performance of enterprises, with 3 measurement scales including (1) Profit or profitability (LN) (for example, return on investment (ROI) of business), customer satisfaction (HL) (for example, providing business value to customers) and market efficiency (HT) (for example, company sales to existing and future customers).

\subsection{Hypotheses development and research model}

The link between social Capital and entrepreneurship

Based on theory and empirical studies, the construction of the conceptual scales for social capital in enterprises is based on the characteristics of social capital. Measurement of social capital is considered in three respective angles: outside the enterprise (BN), inside the enterprise (BT), and the individual leader of the enterprise (LD) (Huynh Thanh Dien, 2012).

Regarding social capital of individual leaders of enterprises (LD), when enterprises own individuals with high qualifications, qualifications and qualities, they will affect the enterprises' capacity and bring about better operational efficiency. Leadership needs a spirit of entrepreneurship, dedication, and reach to create good relationships with external entities (Tushman, 1997), helping leaders to run businesses through difficulties, challenges, always be proactive and innovative. ; willing to take risks to achieve the expected goals most effectively without fear of binding personal responsibilities; thus, the social capital of individual leaders will help improve the entrepreneurship.

For internal social capital (BT), expressed through cooperation, share, support and trust to create better internal communication within the enterprise (Brookes \& et al, 2006); Internal social capital is an important factor for stability because of high trust and consensus; This helps businesses to be confident, proactive, always innovate their operating methods, ready to take risks in order to achieve the expected target set without fear of personal responsibility; thus, the internal social capital helps to promote entrepreneurship.

If the social capital outside the enterprise (BN) is well established, the vertical and horizontal relationships will be good (Yang \& et al, 2011), especially for the authorities (vertically) and with advisory organizations and strategic partners ( horizontally) will help businesses overcome difficulties in administrative procedures, business conditions, technical conditions; help businesses have information, 
useful advice, cooperation contracts for businesses to be proactive, innovative and ready to take risks when fiercely competing without fear of damage when firms face with bad situations; thus, social capital outside the enterprise helps to improve the business spirit; Summary of the three components shows that corporate social capital promotes entrepreneurship. Social capital affects innovation in enterprises (Landry et al., 2000) and social capital also affects entrepreneurship (Cheng-Nan et al., 2007) but has not been tested in Vietnamese SCEs.

Thus, one hypothesis is proposed as follows:

$\boldsymbol{H}_{1}$ :Social Capital has a positive impact on Entrepreneurship of SCEs in Vietnam.

The link between Social Capital and performance

Social capital of individuals who lead good businesses will have relationships and information support from internal and external entities (Tushman, 1997) that bring high results in the process of operation; help improve the performance of businesses.

The internal social capital expressed through cooperation, share, support and trust (Brookes \& et al, 2006) has the effect of reducing transaction costs in a number of business activities, effectively using organizational resources and raising operational efficiency of the enterprise.

Well-built external social capital, the vertical and horizontal relationships will be good (Yang \& et al, 2011), especially for government levels (vertical) and with consulting organizations (horizontal) to help businesses have useful information and advice to be ready to seize the opportunity, bring many high results in the process of operation, help improve the performance of businesses; A combination of the three components suggests that corporate social capital improves operational efficiency; social capital helps reduce risks, affecting operational efficiency (Casey, 2002; Woolcock, 2001; Narayan \& Pritchett, 1999; Dasgupta, 2000) but not yet tested in Vietnamese SCEs. Thus, one hypothesis is proposed as follows:

$\boldsymbol{H}_{2}$ : Social capital has a positive impact on performance of SCEs in Vietnam.

The link between entrepreneurship and performance

The spirit of business helps businesses always be proactive in adapting to all situations, there will be many opportunities to gain competitive advantage; Leading in product innovation and technological innovation to meet market needs, increase customer satisfaction, increase profits and market efficiency. Entrepreneurship also has a direct positive relationship with organizational performance (Sambrook \& Roberts, 2005). Researchers believe that entrepreneurship at an organizational level can improve performance. Thus, the entrepreneurial spirit helps to innovate the management method, helps to reduce management and operation costs; Increasing profits, satisfaction and market efficiency should contribute to improving operational efficiency; Entrepreneurship contributes to creating operational results and is a resource that can create advantages for businesses (Nguyen Thanh Long \& Le Nguyen Hau, 2013) but has not been tested in Vietnamese SCEs Thus, one hypothesis is proposed as follows:

$\boldsymbol{H}_{3}$ : Entrepreneurship has a positive impact on performance of SCEs in Vietnam.

There have been no studies mentioning the three second- order factors structural model in which three concepts (social capital, entrepreneurship and performance), having relationships with each other; so, proposed research model as follows: 


\section{Figure 1. Research model}



Source: proposed by Author

\section{RESEARCH METHODS}

Research process: building the scales of concepts as follow: The scale of leader social capital (LD) has 5 items (from LD1 to LD5); the scale of internal social capital (BT) has 3 items (from BT1 to BT5); the scale of external social capital (BN) has 7 items (from BN1 to BN7); these scales are of enterprise social capital factor adapted and developed from the research of Huynh Thanh Dien (2012).

The scale of proactive (CD) has 4 items (from CD1 to CD4); the scale of innovation (DM) has 4 items (from DM1 to DM4); the scale of risk taking (RR) has 4 items (from RR1 to RR4); these scales are of entrepreneurship factor adapted and developed from the research of Covin \& Slevin (1991), twelve items added.

The scale of customer satisfactory (HL) has 3 items (from HL1 to HL3); the scale of profitability (LN) has 3 items (from LN1 to LN3); the scale of market effectivity (HT) has 3 items (from HT1 to HT3); these scales are of enterprise performance factor inherited from the research of Chu (2015); building hypotheses and research model; preliminary quantitative research is done by sending 100 questionnaires to the SCEs and collecting 60 qualified copies. The results showed that 9 scales of 3 research concepts all met the requirements of the content of each observed variables, about Cronbach alpha and EFA for each concept; after that official quantitative research of sample size of 568 SCEs in Vietnam as of August 2019; testing the scale with SPSS 22.0 software to calculate reliability coefficient (Cronbach's Alpha) and exploratory factor analysis (EFA), use AMOS 22 software to analyze confirmatory factor analysis (CFA); test the research model with the linear structure equation model (SEM), retest the model with Bootstrap with sample size $\mathrm{N}=1000$ to draw conclusions about the model and the hypotheses about the impact of social capital, entrepreneurship to the performance of SCEs in Vietnam.

Characteristics of surveyed sample:

Characteristics of surveyed enterprises: Most types of enterprises are joint stock companies with agricultural capital accounting for $35.7 \%$; The main field of activity is manufacturing, construction up to 
49.6\%; The number of major branches from 1 to 5 branches accounts for 30.6\%; The structure of state capital is slow; Equitization area reached $100 \%$ in the sample; The equitization year focused heavily on the period 2018-2019 due to the time close to collecting information; Business results are mostly from normal to very good.

Characteristics of surveyed individuals: Male and female gender equivalent; Respondents aged 41-50 accounted for the majority of $34.7 \%$; University education accounts for the majority of $49.9 \%$; The leadership positions that answer most are deputy directors to general directors; The main task is senior manager reaching 25.2\%; The common working time in enterprises in group 1 to 6 years is $26.4 \%$; Working time in state-owned enterprises concentrated much about 5 to 10 years, accounting for $36.1 \%$.

General assessment of the factors affecting business performance: the highest level of agreement is $5.23 / 7$ points on average, the lowest is $4.66 / 7$ points. The response of the surveyed object is relatively objective, the observed variables have no overlap.

\section{RESULTS}

\subsection{Testing the scales of constructs by EFA and Cronbach's Alpha}

Cronbach's Alpha reliability coefficient of 9 scales of 3 concepts all variables have item - total correlation coefficient greater than 0.5. All scales meet the Cronbach's Alpha reliability coefficient $(\alpha$ $L D=0.839 ; \alpha B N=0.874 ; \alpha B T=0.766 ;: \alpha C D=0.872 ; \alpha D M=0.829 ; \alpha R R=0.863 ; \alpha H L=0.852 ; \alpha$ $L N=0.868 ; \alpha H T=0.846$ ).

The EFA analysis results show the value of $0.5 \leq \mathrm{KMO}=0.883 \leq 1$; total extracted variance $=$ $60,243>50 \%$ at eigenvalue $=1,248>1$; The maximum factor load factor of each observed variable is $\geq$ 0.5 , indicating that the factor analysis is consistent with the survey data, there are 36 observed variables measuring for 9 factors continue to be used in the research model. All scales are standard for carrying out research in CFA.

\subsection{CFA analysis for full measurement model}

The results of the CFA of the social capital factors of the SCEs show that: Chi-squared $=145,389, p$ $=0,000$. Models with degrees of freedom $\mathrm{df}=87>0$, Chi-squared $/ \mathrm{df}=1,671 \leq 2$ should meet the standard; $0.9 \leq \mathrm{GFI}=0.967 \leq 1 ; 0.9 \leq \mathrm{TLI}=0.980 \leq 1 ; 0.9 \leq \mathrm{CFI}=0.983 \leq 1$ so 3 indicators are very satisfied. RMSEA index $=0.034<0.05$, so the model is very suitable for the whole. The three scales LD, BT and BN all achieve unidimensionality. The scales of LD and BT (estimate 0.583), BT and BN (estimate 0.567 ), $\mathrm{LD}$ and $\mathrm{BN}$ (estimate 0.552 ) have discriminant validity. The observed variables measure

three components LD, BT and BN achieving convergent validity ( lowest $\lambda_{B N 5}=.576$ ); composite reliability, extracted variance of scales LD (0.840 and 0.512$)$, BT (0.767 and 0.524$)$ and $\mathrm{BN}(0.875$ and 0.506) are satisfactory. The indicators show that the SEM model of social capital is consistent with market data.

The CFA results of the entrepreneurship factors of SCEs show that: Chi-squared $=145.389, \mathrm{p}$-value $=$ 0.000 , have degrees of freedom $\mathrm{df}=51>0$, Chi-squared $/ \mathrm{df}=2,525 \leq 3$ should meet standards; $0.9 \leq \mathrm{GFI}$ $=0.964 \leq 1 ; 0.9 \leq \mathrm{TLI}=0.970 \leq 1 ; 0.9 \leq \mathrm{CFI}=0.977 \leq 1$ so 3 indicators are very satisfied. RMSEA index $=0.052<0.08$, so the model is suitable for the whole. The three scales of CD, DM and RR all reach unidimensionality. The scales of CD and DM (estimate 0.446), RR and DM (estimate 0.407), CD and RR (estimate 0.330 ) are discriminant validity. The observed variables measure three $\mathrm{CD}, \mathrm{DM}$ and RR

components achieving convergent validity (Lowest $\lambda_{R R 2}=.624$ ). composite reliability, extracted variance of $C D(0.875$ and 0.637$), D M(0.831$ and 0.553$)$ and $R R(0.867$ and 0.624$)$ scales are all satisfactory. The indicators all show the SEM model of entrepreneurship in line with market data.

The CFA results of the performance factors of SCEs show that: Chi-squared $=47.154, p$-value $=$ 0.003 , degrees of freedom $\mathrm{df}=24>0$, Chi-squared $/ \mathrm{df}=1,965 \leq 2$ should meet standards; $0.9 \leq \mathrm{GFI}=$ $0.982 \leq 1 ; 0.9 \leq \mathrm{TLI}=0.986 \leq 1 ; 0.9 \leq \mathrm{CFI}=0.991 \leq 1$ so 3 indicators are very satisfied. RMSEA index $=0.041<0.05$, so the model is very suitable for the whole. The three scales HL, LN and HT all achieve unidimensionality. The scales LN and HT (estimate 0.406), HL and HT (estimate 0.455), LN and HL 
(estimate 0.399) reach discriminant validity. The observed variables measure the three components HL,

LN and HT achieving convergent validity (Lowest $\lambda_{H L 3}=.742$ ). The composite reliability of the LN (0.870 and 0.691) and HT (0.847 and 0.648) scales are satisfactory; only the composite reliability of the HL (0.691 and 0.652) scale is nearly satisfactory, the extracted variance of the 3 scales is satisfactory. The indicators all show the SEM model of performance consistent with market data.

The CFA results of three concept in the critical measurement model of SCEs show that: Chi-squared $=1370,892, \mathrm{p}$-value $=0.000$, have degrees of freedom $\mathrm{df}=582>0$, Chi-squared $/ \mathrm{df}=2,355 \leq 3 ; 0.8 \leq$ $\mathrm{GFI}=0.878 \leq 1 ; 0.9 \leq \mathrm{TLI}=0.916 \leq 1 ; 0.9 \leq \mathrm{CFI}=0.922 \leq 1$ so 3 indexes are satisfied. $\mathrm{RMSEA}$ index $=$ $0.049<0.05$, so the model is very suitable for the whole. The three concepts of social capital, entrepreneurship, and performance all achieve unidimensionality. The concept of social capital and entrepreneurship (correlation with estimate 0.591), social capital and operational efficiency (correlation with estimate 0.387), entrepreneurship and operational efficiency (correlation with estimate 0.443) all have discriminant validity. Observed variables measure three components $\mathrm{LD}, \mathrm{BT}$ and $\mathrm{BN}$; three components CD, DM and RR; The three components HL, LN and HT all achieve convergent validity

(Lowest $\lambda_{L N}=.516$ ); The composite reliability of the three concepts is close to satisfactory, extracted variance of social capital concept $(0.795$ and 0.565$)$ is satisfactory, extracted variance of the entrepreneurship (0.666 and 0.403$)$ and performance $(0.680$ and 0.423$)$ are near-satisfactory.

Figure 2. CFA analysis

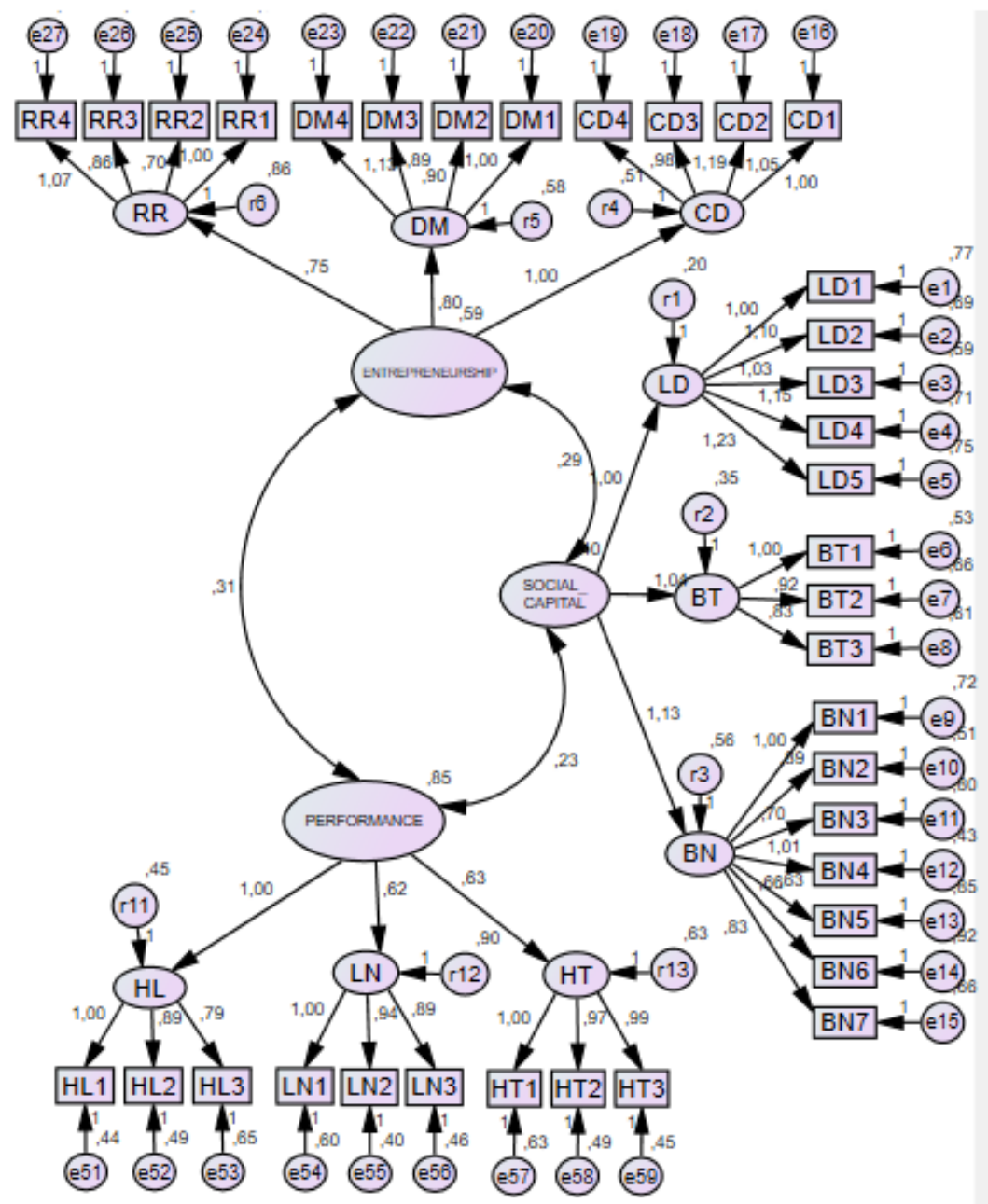

Chi-square $=1370,892 ; \mathrm{df}=582 ; \mathrm{P}=, 000 ;$ Chi-square $/ \mathrm{df}=2,355$ $; \mathrm{GFI}=, 878 ; \mathrm{TLI}=, 916 ; \mathrm{CFI}=, 922 ; \mathrm{RMSEA}=, 049$ 


\subsection{Testing Hypotheses, model by SEM:}

Three hypotheses $\mathrm{H} 1, \mathrm{H} 2$ and $\mathrm{H} 3$ are accepted because of $\mathrm{P}$-value $=0.000$ and estimates as follows:

Social capital --> Entrepreneurship (0.591)

Social capital --> Performance (0.193)

Entrepreneurship --> Performance (0.329)

SEM results of the standardized structure model show that the theoretical model is suitable for market data $($ Chi-squared $=1370,892, \mathrm{p}$-value $=0.000$, have degrees of freedom $\mathrm{df}=582>0$, Chi-squared $/ \mathrm{df}=$ $2,355 \leq 3 ; 0.8 \leq \mathrm{GFI}=0.878 \leq 1 ; 0.9 \leq \mathrm{TLI}=0.916 \leq 1 ; 0.9 \leq \mathrm{CFI}=0.922 \leq 1$ so 3 indexes are satisfied. RMSEA index $=0.049<0.05$, so the model is very suitable for the whole)

Figure 3. SEM testing

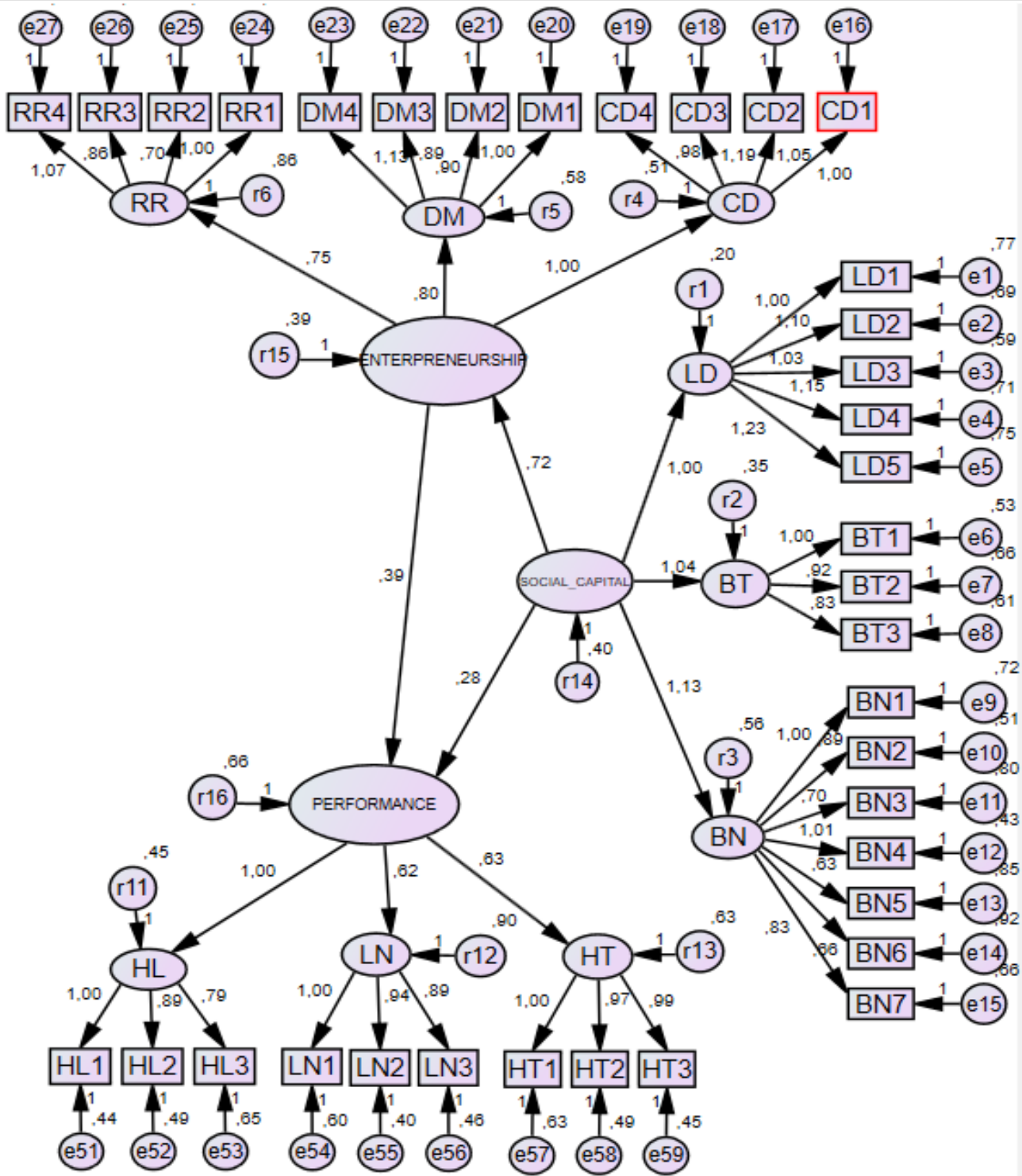

Chi-square $=1370,892 ; \mathrm{df}=582 ; \mathrm{P}=, 000 ;$ Chi-square $/ \mathrm{df}=2,355$ $\mathrm{GFI}=, 878 ; \mathrm{TLI}=, 916 ; \mathrm{CFI}=, 922 ; \mathrm{RMSEA}=, 049$

This study uses Bootstrap with the number of repeating samples $\mathrm{N}=1000$, with the critical value C.R in the table shows are less than 1.96, so the estimates in the model have high reliability. 


\section{DISCUSSION AND CONCLUSION}

- Since social capital had a positive impact on entrepreneurship (estimate 0.591), SCEs have to increasingly increase their social capital to promote entrepreneurship.

- Social capital and entrepreneurship all have positive impacts on performance (estimate 0.193 and 0.329), so SCEs must increasingly increase social capital and promote entrepreneurship, helping business enterprises to be profitable, survive and develop sustainably. Enterprises will be Sustainable development over time.

- It is the entrepreneurship that is an important factor for businesses to be proactive and innovate to lead in technology and products; helping enterprises be autonomous and fiercely competitive despite all difficulties and challenges, so SCEs must pay special attention to building businesses with strong business spirit to promote performance ( because of estimate 0.329 was very high) .

\subsection{Theoretical implications}

Firstly, this study confirmed the impact of social capital, entrepreneurship on the performance of Vietnamese SCEs; A specific type of enterprise is in the process of transformation, restructuring to perfection.

Secondly, this study examined the combined intangible resources including social capital, entrepreneurship and their impact on the performance of SCEs.

Thirdly, this study contributed to perfecting the entrepreneurship scale by showing the observed items for components: proactive, innovation and risk taking (twelve items developed).

Fourth, this research shows that social capital had indirect effects on business performance through entrepreneurship.

Finally, this study contributed to the theoretical treasure of a three second-order factors structure model that represents the correlation between factors (social capital had a positive impact on entrepreneurship; social capital had a positive impact indirectly on performance through entrepreneurship); reaffirmed their importance and impacts on performance.

\subsection{Managerial Implication}

- Raising awareness of the spirit of initiative and coordination: smoothly combining intangible social capital resources, adaptive capacity; improve the spirit of coordination of individuals and divisions in the enterprise in a proactive, creative and innovative way; coordinate in predicting and forecasting quickly and promptly; allocating resources in a quick, flexible and appropriate manner; The spirit of coordination is the foundation for individuals to contribute to the construction of SCEs.

- Eliminate dependence and avoid collisions: dismantling the state subsidy mechanism is the basis of dependence and dependence of SCEs.

- Focusing on the sustainability of the operation and life cycle of SCEs: not for the huge profit in the short term but forgetting to plan a stable and sustainable development strategy over time.

- Effective exploitation, use and coordination of intangible resources: SCEs need to identify each intangible resource and their important to ensure that SCEs can compete healthily with other types; importance in indirectly effectively exploiting material resources of enterprises and operate effectively in the long run, meeting the expectations of the state.

- Reasonable performance allocation and terminating thinking in administration term: SCE managers also have term tenure thinking so they often care about what happens in the short term; do what is beneficial for the immediate future, but also invest, plan for the far future is not interested; for SCEs to operate effectively and sustainably, they must reasonably allocate the achievements of businesses and eliminate the tenure mindset.

\subsection{Limitations and future research:}

Firstly, the research data collected in this study by non-probability sampling method can make the representative of the sample not high.

Secondly, this study was conducted for only one type of SCE enterprise, and there may be differences in the measurement scale in other types of enterprises. 
Thirdly, the scope of this study was conducted throughout the territory of Vietnam: survey questionnaires collected about scattered allocation in many sectors and fields. Further research should take research data in specific areas.

Fourth, this study examines only three components of entrepreneurship (proactive, innovation and risk taking); Further studies should use two more components: autonomy and aggressive competition (Lumpkin \& Dess, 1996).

Fifth, this study is conducted in the Vietnamese context; Further studies should be conducted in countries with transition economies such as Vietnam.

Finally, this study achieves its goal of general research by combining two intangible resources: social capital and entrepreneurship ; These resources will increase indirectly the efficiency of using tangible physical resources and increase the performance of SCEs.

\section{REFERENCES}

[1] Bourdieu, P. (2011). The forms of capital (1986). Cultural theory: An anthology, 1, 81-93.

[2] Burgers, J. H., \& Covin, J. G. (2016). The contingent effects of differentiation and integration on corporate entrepreneurship. Strategic Management Journal, 37(3), 521-540.

[3] Chen, C. N., Tzeng, L. C., Ou, W. M., \& Chang, K. T. (2007). The relationship among social capital, entrepreneurial orientation, organizational resources and entrepreneurial performance for new ventures. Contemporary management research, 3(3).

[4] Cheng, T., Yip, F., \& Yeung, A. (2012). Supply risk management via guanxi in the chinese business context: The buyer's perspective. International Journal of Production Economics, 139(1), 3-13.

[5] Coleman, J. S. (1994). Social capital, human capital, and investment in youth. Youth unemployment and society, 34 .

[6] Covin, J. G., \& Slevin, D. P. (1991). A conceptual model of entrepreneurship as firm behavior. Entrepreneurship theory and practice, 16(1), 7-26.

[7] Fukuyama, F. (2001). Social capital, civil society and development. Third world quarterly, 22(1), 7-20.

[8] Hair, J. F., Black, W. C., Babin, B. J., Anderson, R. E., \& Tatham, R. (2010). L.(2010). Multivariate data analysis. Pearson.

[9] Hoang Trong \& Chu Nguyen Mong Ngoc. (2008). Phân tích dữ liệu nghiên cứu với SPSS (tập 2). NXB Hồng Đúc

[10] Lumpkin, G. T., \& Dess, G. G. (1996). Clarifying the entrepreneurial orientation construct and linking it to performance. Academy of management Review, 21(1), pp.135-172.

[11] March, J. G. (1991). Exploration and exploitation in organizational learning. Organization science, 2(1), 7187.

[12] Nguyen Thanh Long \& Le Nguyen Hau. (2013). Một mô hình lý thuyết về năng lực doanh nhân, vốn xã hội và sáng nghiệp công ty trong các $\mathrm{DN}$ vừa và nhỏ. Tạp chí phát triển $K H \& C N$, tập 16, số Q2-2013, trường Đại học Bách Khoa, Đại học Quốc Gia TP.HCM.

[13] Nguyen Trong Hoai \& Huynh Thanh Dien. (2010). Xây dựng khung phân tích vốn xã hội trong DN cho điều kiện Việt Nam, tổng quan lý thuyết và các nghiên cứu thực nghiệm, Phát triển và họi nhập, số 6 , tháng $8 / 2010$. 


\section{TÁC ĐộNG CỦA VỐN XÃ HộI, TINH THẦN KINH DOANH ĐẾN HIỆU QUẢ HOẠT ĐỘNG CỦA DOANH NGHIỆP CÓ VỐN NHÀ NƯỚC TẠI VIỆT NAM}

Tóm tắt. Với nỗ lục không ngùng, Chính phủ Việt Nam đang tiến hành sắp xếp, cơ cấu lai doanh nghiệp nhà nước (DNNN) để hình thành doanh nghiệp có vốn nhà nước (DNCVNN); hiện có nhiều nghiên cứu về tái cấu trúc, cổ phần hóa DNNN nhưng it có nghiên cưu về việc kết hợp hai nguồn lực vô hình vốn xã họi và tinh thần kinh doanh mặc dù nhũng nguồn lực vô hình này gián tiếp làm gia tăng hiệu quả sủ dụng nguồn lực vật chất, hưu hình khác. Nghiên cứu này trình bày mô hình cấu trúc mô tả: (i) tác động của vốn xã hội và tinh thần kinh doanh đến hiệu quả hoạt động DNCVNN Việt Nam và (ii) vốn xã hội tác động gián tiếp đến hiệu quả hoạt động thông qua tinh thẩn kinh doanh. Sau khi hiệu chỉnh thang đo qua phỏng vấn chuyên sâu các chuyên gia; tiến hành nghiên cứu định lượng khảo sát mẫu 568 DNCVNN Việt Nam để kiểm tra độ tin cậy Cronbach's Alpha, phân tích EFA, CFA và kiểm định SEM nhằm kết luận về ba giả thuyết và mô hình; kết quả nghiên cứu cho thấy (i) vốn xã hội, tinh thần kinh doanh có tác động tích cực đến hiệu quả hoạt động của DNCVNN Việt Nam và (ii) vốn xã hội gián tiếp tác động duơng đển hiệu quả hoạt động thông qua tinh thần kinh doanh. Nghiên cúu cũng đề xuất hàm ý quản trị về sử dụng hơp lý, hiệu quả các nguồn lục trong DNCVNN Việt Nam để cải thiện hiệu quả hoạt động.

Từ khóa. Vốn xã hội doanh nghiệp, tinh thần kinh doanh, hiệu quả hoạt động, DNNN, DNCVNN.

Ngày nhận bài: 10/02/2020

Ngày chấp nhận đăng: 28/02/2020 